\section{Low ozone concentrations stimulate cytoskeletal organization, mitochondrial activity and nuclear transcription}

\author{
M. Costanzo, ${ }^{1}$ B. Cisterna, ${ }^{1}$ A. Vella, ${ }^{2}$ \\ T. Cestari, ${ }^{2}$ V. Covi, ${ }^{3}$ G. Tabaracci, ${ }^{3}$ \\ M. Malatesta ${ }^{1}$ \\ 'Department of Neurological \\ and Movement Sciences, Anatomy and \\ Histology Section, University of Verona \\ 2Department of Pathology \\ and Diagnostics, Immunology Section, \\ University of Verona \\ ${ }^{3}$ San Rocco Clinic, Montichiari (BS), Italy
}

\section{Abstract}

Ozone therapy is a modestly invasive procedure based on the regeneration capabilities of low ozone concentrations and used in medicine as an alternative/adjuvant treatment for different diseases. However, the cellular mechanisms accounting for the positive effects of mild ozonization are still largely unexplored. To this aim, in the present study the effects of low ozone concentrations ( 1 to $20 \mu \mathrm{g} \mathrm{O}_{3} / \mathrm{mL}$ $\mathrm{O}_{2}$ ) on structural and functional cell features have been investigated in vitro by using morphological, morphometrical, cytochemical and immunocytochemical techniques at bright field, fluorescence and transmission electron microscopy. Cells exposed to pure $\mathrm{O}_{2}$ or air served as controls. The results demonstrated that the effects of ozone administration are dependent on gas concentration, and the cytoskeletal organization, mitochondrial activity and nuclear transcription may be differently affected. This suggests that, to ensure effective and permanent metabolic cell activation, ozone treatments should take into account the cytological and cytokinetic features of the different tissues.

\section{Introduction}

Ozone therapy is a modestly invasive procedure based on the regeneration capabilities of low ozone concentrations and used in medicine as an alternative/adjuvant treatment for different diseases, among which arthritis, heart and vascular diseases, asthma, emphysema, multiple sclerosis (reviews in ${ }^{1-3}$ ). Ozone treatment has also been proposed to improve metabolic activities in elderly. ${ }^{4-6}$
Despite ozone has been applied for therapy since the end of the $18^{\text {th }}$ century, the cellular mechanisms accounting for the positive effects of ozone treatment, especially at low concentrations, are still largely unexplored (for a scientific overview of ozone therapy, see $^{7}$ ). Molecular evidence shed light on some biological mechanisms responsible for the dose-dependent effects of ozone treatment: high dosages stimulate severe oxidative stress (via activation of nuclear transcriptional factor kappa $\mathrm{B}$, resulting in inflammatory response and tissue injury); on the contrary, low ozone concentrations induce a moderate oxidative stress which activates the nuclear factor erythroid 2-related factor 2 as well as several antioxidant enzymes (e.g., superoxide dismutases, glutathione peroxidase, glutathione transferases, catalase, heat shock proteins), thus protecting cells from oxidation and suppressing inflammatory responses (review in ${ }^{8}$ ). Although some biological effects of ozone administration in vivo are likely mediated by blood factors, a direct cellular influence cannot be excluded, especially when ozone is administered by injection in a tissue or by contact with an epithelium. However, knowledge of the effects of low ozone concentrations on cell dynamics and organelles' structure and function is still lacking.

In order to identify the cellular mechanisms responsible for the regeneration capabilities of mild ozonization, in the present study the effects of low ozone concentrations on structural and functional cell features have been investigated by using morphological, morphometrical, cytochemical and immunocytochemical techniques at bright field, fluorescence and transmission electron microscopy. An in vitro cell system has been employed to allow analyses under controlled experimental conditions.

\section{Materials and Methods}

\section{Cell culture and ozone treatment}

HeLa cells $\left(5 \times 10^{4}\right)$ were grown on $75 \mathrm{~cm}^{2}$ plastic flasks (Corning Inc., Corning, NY, USA) in DMEM (Dulbecco Modified Eagles Medium) supplemented with $10 \%(\mathrm{v} / \mathrm{v})$ fetal calf serum, $1 \%(\mathrm{w} / \mathrm{v})$ glutamine, $100 \mathrm{U}$ of penicillin and $100 \mathrm{~g} / \mathrm{mL}$ streptomycin (Celbio, Milan, Italy), at $37^{\circ} \mathrm{C}$ in a $5 \% \mathrm{CO}_{2}$ humidified atmosphere. When subconfluent, the cells were trypsinized (0.25\% trypsin containing $0.05 \%$ ethylene diamino tetraacetic acid (EDTA) in phosphatebuffered saline, PBS) and exposed in suspension to $\mathrm{O}_{2}-\mathrm{O}_{3}$ gas mixtures with different $\mathrm{O}_{3}$ concentrations $\left(1,10\right.$ and $20 \mu \mathrm{g} 0_{3} / \mathrm{mL} \mathrm{O}_{2}$ ) using an 0ZO2 FUTURA apparatus (Alnitec s.r.l., Cremosano, CR, Italy) which generates $\mathrm{O}_{3}$ from medical-grade $\mathrm{O}_{2}$, and allows photo-
Correspondence: Manuela Malatesta, Department of Neurological and Movement Sciences, Anatomy and Histology Section, University of Verona, Strada Le Grazie 8, 37134 Verona, Italy.

Tel. +39.045.8027157

E-mail:manuela.malatesta@univr.it

Key words: Ozone, in vitro culture, epithelial cells, cell nucleus, cytoskeleton, mitochondria, heat shock proteins.

Received for publication: 3 March 2015.

Accepted for publication: 4 April 2015.

This work is licensed under a Creative Commons Attribution NonCommercial 3.0 License (CC BYNC 3.0).

(C) Copyright M. Costanzo et al., 2015

Licensee PAGEPress, Italy

European Journal of Histochemistry 2015; 59:2515 doi:10.4081/ejh.2015.2515

metric real-time control of gas flow rate and $\mathrm{O}_{3}$ concentration. The experimental procedure was set up according as previsously described: ${ }^{9}$ in detail, for each sample, $4 \times 10^{5}$ cells were suspended in $1 \mathrm{~mL}$ medium into a $10 \mathrm{~mL}$ polypropylene $\left(\mathrm{O}_{3}\right.$ resistant) syringe (Terumo Medical Corporation, Somerset, NJ, USA); an equal volume of gas was then collected in the syringe (thus having the final gas pressure corresponding to the atmospheric one) through a sterile filter (Alnitec s.r.l.) in order to avoid contamination. The sample was gently and continuously mixed with the gas mixture for $10 \mathrm{~min}$ : it has been ascertained that during this period of time cell samples react with the ozone dose totally. ${ }^{9}$ Cells exposed to pure $\mathrm{O}_{2}$ under the same experimental conditions were used to discriminate the effect of $\mathrm{O}_{3}$ while cells exposed to air (CTR) served as controls. After treatment, the cells were seeded in 6 or 12 multiwell plastic microplates (Corning) and analysed at increasing times after seeding in order to evaluate some fundamental features of cell morphology and function (see below) (for fluorescence microscopy, the cells were planted on glass coverslips placed on the wells' bottom).

\section{Cell viability and proliferation}

To determine the effect of gas exposure on cell survival, $2 \times 10^{4}$ cells/well were seeded on 12 multiwell plastic microplates. The fraction of dead cells was estimated after different times from the treatment after staining for 2 min with $0.1 \%$ Trypan blue in the culture medium. Using a Leica DM IL inverted microscope equipped with $20 \mathrm{x}$ objective lens, the cells were counted at increasing times in 15 randomly chosen microscope fields and the percentage of dead (Trypan blue-positive) cells was estimated. Data were expressed as the 
mean of three independent experiments \pm standard error (SE).

To evaluate cell growth, $5 \times 10^{4}$ cells/well were seeded on 6 multiwell plastic microplates and the total cell number was estimated after different times from the treatment. The cells were detached by mild trypsinization and counted in a Burker hemocytometer. Data were expressed as the mean of three independent experiments \pm standard error (SE). In order to evaluate $\mathrm{S}$ phase cells, $24 \mathrm{~h}$ and $48 \mathrm{~h}$ after treatment cells grown on coverslips were pulse-labeled with 20 $\mu \mathrm{M}$ Bromodeoxyuridine (BrdU, Sigma-Aldrich, St. Louis, M0, USA) for $30 \mathrm{~min}$ at $37^{\circ} \mathrm{C}$, then fixed with $70 \%$ ethanol and incubated for 20 min at room temperature in $2 \mathrm{~N} \mathrm{HCl}$, to denature DNA partially; after neutralization with $0.1 \mathrm{M}$ sodium tetraborate ( $\mathrm{pH} 8.2$ ) for $3 \mathrm{~min}$, samples were washed in PBS, permeabilized for 15 min in PBS containing $0.1 \%$ bovine serum albumin and $0.05 \%$ Tween-20, and incubated for $1 \mathrm{~h}$ with a mouse monoclonal antibody recognizing BrdU (BD, Franklin Lakes, NJ, USA) diluted 1:20. After two washings with PBS, samples were incubated for $1 \mathrm{~h}$ with an Alexafluor 488conjugated anti-mouse secondary antibody (Molecular Probes, Invitrogen, Milan, Italy), diluted 1:200. The cell samples were washed with PBS, stained for 10 min with $1 \mu \mathrm{g} / \mathrm{mL}$ Hoechst 33342 in PBS, and finally mounted in PBS:glycerol (1:1) to be observed and scored in fluorescence microscopy (see below). The percentage of apoptotic cells (identified by chromatin morphology) was also estimated in these samples. Data were expressed as the mean of three independent experiments \pm standard error (SE).

\section{Cell adhesion and flattening}

To test the ability of HeLa cells to restore their typical morphology after the treatment in suspension, $2 \times 10^{4}$ cells/well were seeded on 12-multiwell plastic microplates; using a Leica DM IL inverted microscope equipped with 40x objective lens, the adherent cells were counted at increasing times ( $30 \mathrm{~min}, 1 \mathrm{~h}, 2 \mathrm{~h}, 4 \mathrm{~h}, 6 \mathrm{~h})$ in 15 randomly chosen microscope fields. The percentage of flattened cells was also calculated. Results were expressed as the mean \pm SE of three independent experiments.

In order to visualise the cytoskeletal microfilament arrangement, $24 \mathrm{~h}$ after treatment and seeding on glass coverslips, some HeLa cells were fixed with $4 \%(\mathrm{v} / \mathrm{v})$ formaldehyde (30 min at room temperature) and $70 \%(\mathrm{v} / \mathrm{v})$ ethanol in water $\left(30 \mathrm{~min}\right.$ at $\left.-20^{\circ} \mathrm{C}\right)$, rehydrated with $\mathrm{PBS}$, incubated with Alexa 594-conjugated phalloidin (Molecular Probes, Invitrogen) diluted 1:40 in PBS for $1 \mathrm{~h}$ at room temperature, stained for DNA with Hoechst $33342(0.1 \mathrm{~g} / \mathrm{mL}$ in PBS for $10 \mathrm{~min}$ ), rinsed in PBS, counterstained with Trypan blue, washed in PBS and finally mounted in a 1:1 PBS:glycerol mixture.
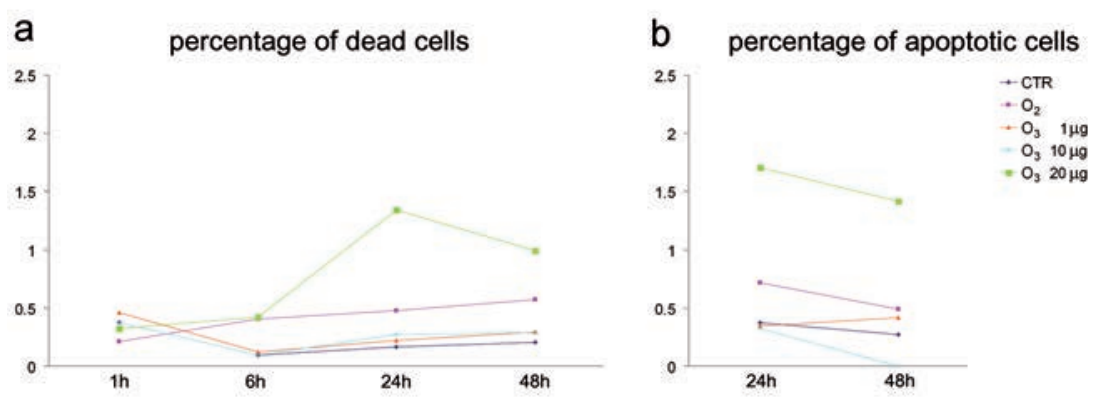

Figure 1. Effect of $\mathrm{O}_{3}$ exposure on cell death and apoptosis. a) Mean values of dead cell and b) apoptotic cell percentage. The values are not significantly different from each other, although $20 \mu \mathrm{g} \mathrm{O} / \mathrm{mL}$-treated cells show higher percentages; $\mathrm{SE}$ values have been omitted to improve graph readability.

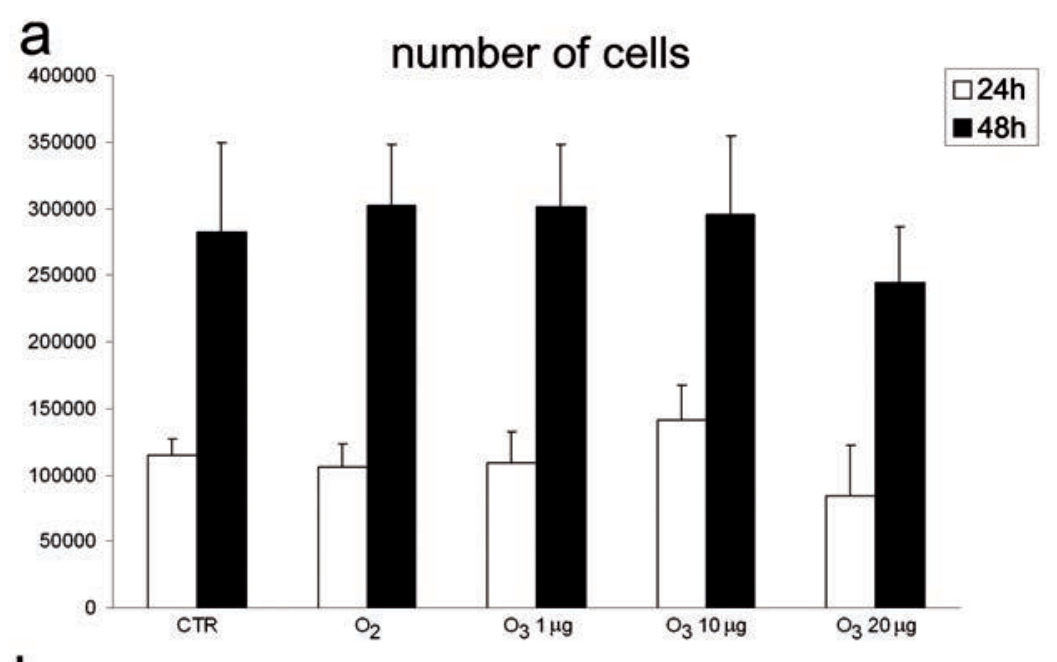

b
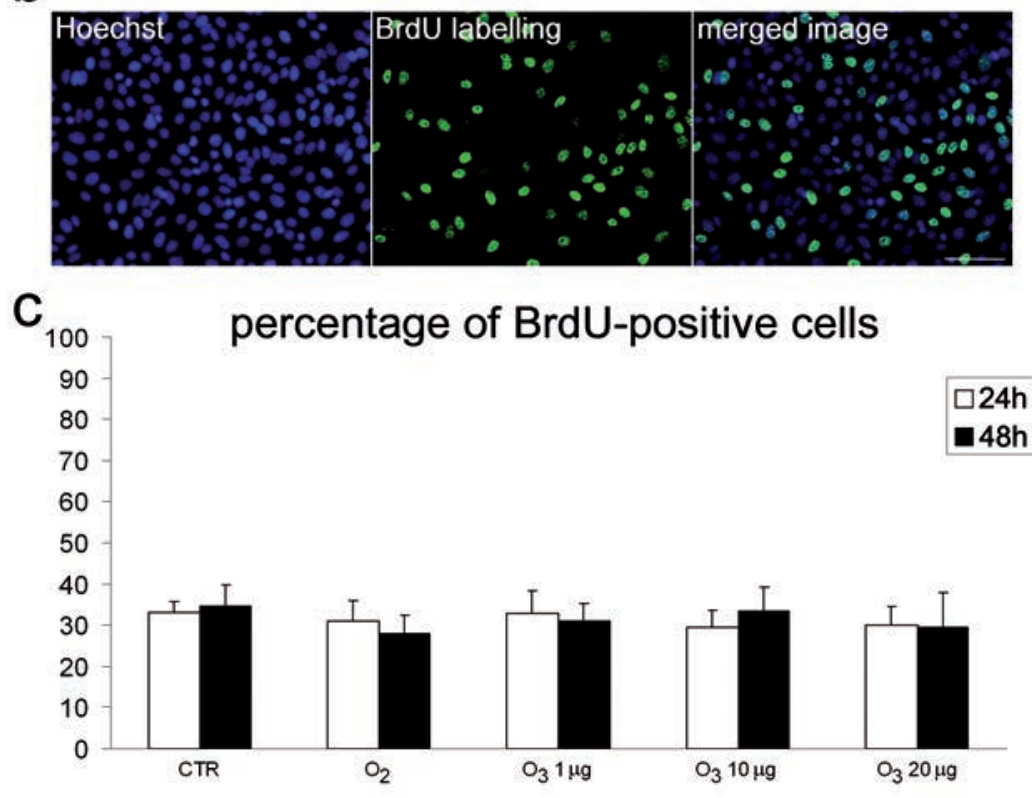

Figure 2. Effect of $\mathrm{O}_{3}$ exposure on cell proliferation. a) Mean values $\pm \mathrm{SE}$ of cell number $24 \mathrm{~h}$ and $48 \mathrm{~h}$ post-treatment; no significant difference has been found among experimental groups at the same time. b) Representative fluorescence micrographs of HeLa cells after BrdU incorporation; scale bar: $50 \mu \mathrm{m}$. c) Mean values $\pm S E$ of BrdU-positive cell percentage $24 \mathrm{~h}$ and $48 \mathrm{~h}$ post-treatment; no significant difference has been found among experimental groups. 


\section{In situ detection of Reactive Oxygen Species}

The intracellular sites of the Reactive Oxygen Species (superoxide anion radical and possibly singlet oxygen; ROS) production were visualised by the cytochemical method based on a 3,3'-Diaminobenzidine (DAB)- $\mathrm{Mn}^{2+}-\mathrm{Co}^{2+}$ reaction. ${ }^{10}$ Briefly, 30 min and 5 h post-treatment HeLa cells were incubated for $30 \mathrm{~min}$ in a medium containing $12.5 \mathrm{mM}$ DAB, $5 \mathrm{mM}$ $\mathrm{MnCl}_{2}$ and $40 \mathrm{mM} \mathrm{CoCl}$ dissolved in $10 \% \mathrm{w} / \mathrm{v}$ polyvinyl alcohol, in $100 \mathrm{mM}$ Tris-maleate buffer $\mathrm{pH} 8.0$ at $37^{\circ} \mathrm{C}$. The cells were then extensively rinsed in hot $\left(60^{\circ} \mathrm{C}\right)$ distilled water and finally mounted in PBS:glycerol (1:1). As a positive control of the cytochemical reaction HeLa cells treated with $9.8 \mathrm{M} \mathrm{H}_{2} \mathrm{O}_{2}$ for $2 \mathrm{~h}$ at $37^{\circ} \mathrm{C}$ were treated as above. The samples were observed at differential interference contrast (DIC) using an Olympus BX51 microscope. Data were expressed as the mean of three independent experiments \pm standard error (SE).

\section{Mitochondrial membrane potential}

The changes in the mitochondrial membrane potential were monitored using JC-1 (5,5V,6,6V-tetrachloro-1,1V,3,3V-tetraethylbenzimidazolcarbocyanine iodide) (Invitrogen, Carlsbad, CA, USA). When administered to living cells, JC-1 accumulates in the mitochondria where it emits either red or green fluorescence, depending on the mitochondrial membrane potential, the red signal indicating polarized mitochondria, and the green signal the depolarized ones; ${ }^{11}$ therefore, the shift from red to green fluorescence is considered a reliable indication of a drop in the mitochondrial membrane potential. HeLa cells were harvested by mild trypsinisation after $24 \mathrm{~h}$ post-treatment, and incubated in culture medium with $2 \mu \mathrm{M} \mathrm{JC}-1$ for $20 \mathrm{~min}$ at $37^{\circ} \mathrm{C}$ in the dark.

Cells were washed in PBS at $37^{\circ} \mathrm{C}$ and measured on a 10 color, 3 laser (Blue Solid State Diode: $488 \mathrm{~nm}, 22 \mathrm{~mW}$; Red Solid State Diode: 638 nm, 25 mW; Violet Solid State Diode: 405 $\mathrm{nm}, 40 \mathrm{~mW}$ ), Navios flow cytometer (Beckman Coulter Inc., Brea, CA, USA). When exited at $488 \mathrm{~nm}$, JC-1 monomers emit green fluorescence (FL1 channel) with a maximum at 530 $\mathrm{nm}$, whereas JC-1 aggregates emit orange-red fluorescence (FL2 channel) with a maximum at $595 \mathrm{~nm}$. In order to evaluate cellular autofluorescence and FL2/FL2 spectral fluorescence compensation we prepared three controls tube as follow: JC-1 unloaded cells in PBS (control for autofluorescence), JC-1 loaded cells treated with 70\% ethanol in PBS (positive green and negative red fluorescence), JC-1 loaded, untreated cells in PBS (double positive red and green fluorescence). All acquired data files were analyzed using the Kaluza software, version 1.3 (Beckman Coulter). Cell doublets were excluded using side scatter peak (high) versus side scatter integral (area).

\section{Immunofluorescence microscopy}

For immunolabelling at fluorescence microscopy, the cells were treated for $15 \mathrm{~min}$ with PBS containing $0.1 \%$ bovine serum albumin and $0.05 \%$ Tween-20, and then incubated for $2 \mathrm{~h}$ at room temperature with the primary antibodies. After washing with PBS, samples were incubated for $1 \mathrm{~h}$ with Alexafluor 488conjugated anti-mouse or Alexafluor 594-con-
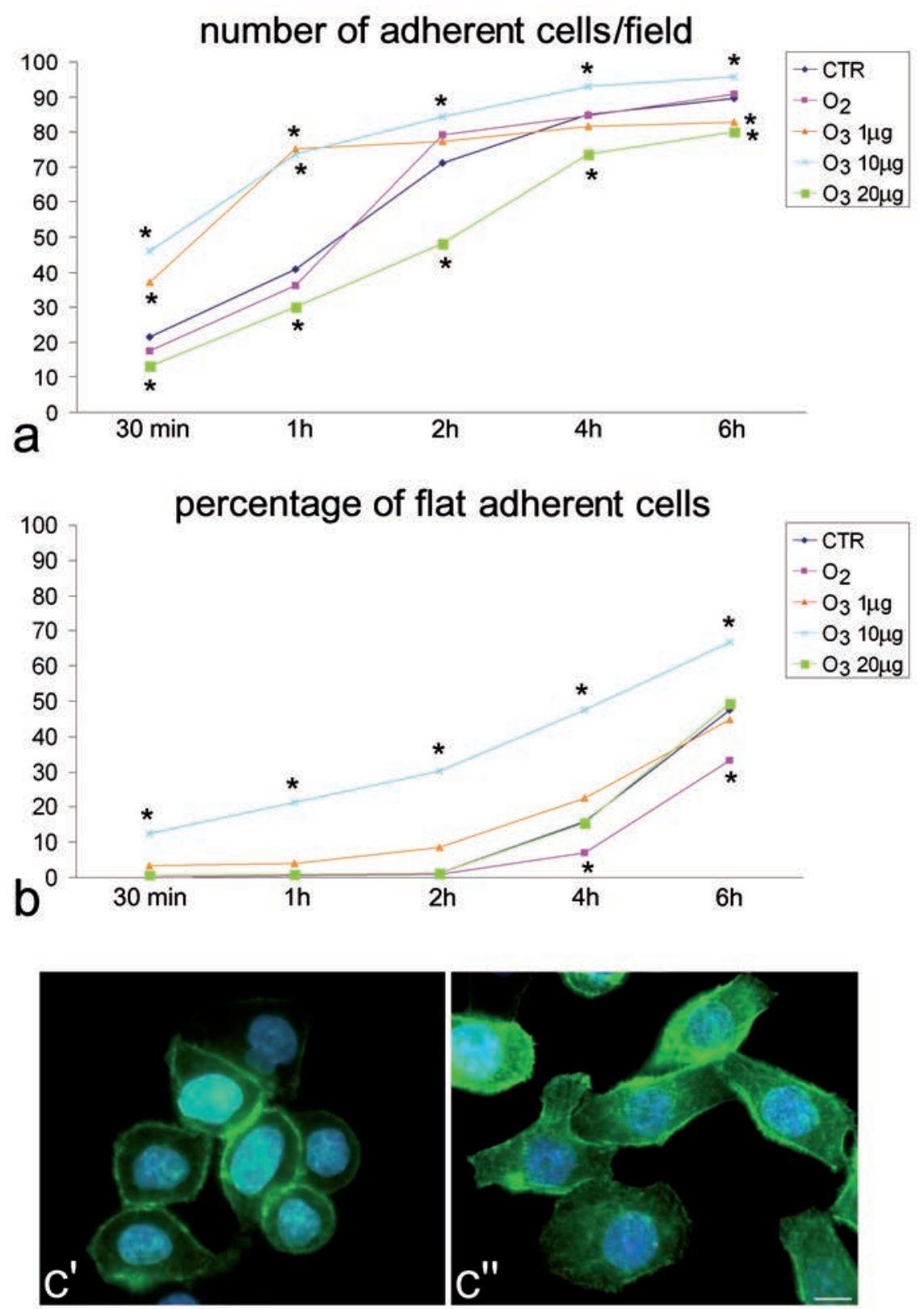

Figure 3. Effect of $\mathrm{O}_{3}$ exposure on cell adhesion. a) Mean values of the number of adherent cells per optical field and b) percentage of flat adherent cells, evaluated at increasing times after post-treatment seeding; asterisks indicate values significantly different from CTR; SE values have been omitted to improve graph readability. c', c") Fluorescence micrographs of CTR and $10 \mu \mathrm{g} \mathrm{O} / \mathrm{mL}$-treated cells $24 \mathrm{~h}$ after treatment and seeding. cytoskeletal actin was labelled with FITC-conjugated phalloidin (green); nuclear DNA was stained with Hoechst (blue); $\mathrm{O}_{3} 10 \mu \mathrm{g} \mathrm{O} / \mathrm{mL}$-treated cells are apparently flatter and the actin filaments more organized: scale bar: $10 \mu \mathrm{m}$. 
jugated anti-rabbit or Alexafluor 594-conjugated anti-human secondary antibodies (Molecular Probes, Invitrogen), diluted 1:200. Cells were washed with PBS, stained for $5 \mathrm{~min}$ with Hoechst 33342 in PBS, and finally mounted in PBS:glycerol (1:1). Mouse monoclonal antibodies directed against Hsp70 (Abcam, Cambridge, UK) or mitochondrial Hsp70 (mtHsp70; Enzo Life Sciences, Farmingdale, NY, USA), and a human autoimmune serum recognizing the mitochondrial $70 \mathrm{kDa}$ E2 subunit of the pyruvate dehydrogenase complex ${ }^{12}$ were used as primary antibodies. Dual immunolabellings were also performed.

An Olympus BX51 microscope equipped with a 100W mercury lamp (Olympus Italia S.r.l., Milan, Italy) was used under the following conditions: $450-480 \mathrm{~nm}$ excitation filter (excf), $500 \mathrm{~nm}$ dichroic mirror (dm), and $515 \mathrm{~nm}$ barrier filter (bf) for Alexa 488 and for JC-1; 540 $\mathrm{nm}$ excf, $580 \mathrm{~nm} \mathrm{dm}$, and $620 \mathrm{~nm}$ bf for Alexa $594 ; 330-385 \mathrm{~nm}$ excf, $400 \mathrm{~nm} \mathrm{dm}$, and $420 \mathrm{~nm}$ bf, for Hoechst 33342. Images were recorded with an Olympus Magnifire digital camera system (Olympus Italia S.r.l.).

\section{Ultrastructural morphology and immunocytochemistry}

Cells from three independent experiments were processed for transmission electron microscopy $24 \mathrm{~h}$ after treatment. For conventional morphology, cells were fixed with 2.5\% $(\mathrm{v} / \mathrm{v}) \quad$ glutaraldehyde and $2 \% \quad(\mathrm{v} / \mathrm{v})$ paraformaldehyde in $0.1 \mathrm{M}$ Sörensen phosphate buffer, $\mathrm{pH} 7.4$, at $4^{\circ} \mathrm{C}$ for $1 \mathrm{~h}$, washed, post-fixed with $1 \% \mathrm{OsO}_{4}$ at $4^{\circ} \mathrm{C}$ for $30 \mathrm{~min}$, dehydrated with acetone and embedded in Epon. For immunoelectron microscopy, cells were fixed with $4 \%$ paraformaldehyde in $0.1 \mathrm{M}$ Sörensen phosphate buffer at $4^{\circ} \mathrm{C}$ for $1 \mathrm{~h}$, washed, treated with $0.5 \mathrm{M} \mathrm{NH}_{4} \mathrm{Cl}$ in PBS, dehydrated with ethanol and embedded in LRWhite resin. In order to evaluate RNA transcription rate, some cells were pulse-labelled with $10 \mathrm{mM} \mathrm{BrU}$ (5-bromouridine, Sigma-Aldrich) for $10 \mathrm{~min}$ at $37^{\circ} \mathrm{C}$, and then fixed and processed for immunoelectron microscopy as above. Ultrathin sections from Epon-embedded samples were conventionally stained with lead citrate and observed. A morphometrical analysis was carried out in fifty mitochondria $(\mathrm{x} 28,000)$ per sample: mitochondrial area and the ratio between inner and outer membranes (estimating the extension of cristae independently of mitochondrial size) were considered. Ultrathin sections from LRWhite-embedded samples were processed for immunocytochemistry as follows: they were floated for $3 \mathrm{~min}$ on normal goat serum diluted 1:100 in PBS and then incubated for $17 \mathrm{~h}$ at $4^{\circ} \mathrm{C}$ with the primary antibody diluted in PBS containing 0.1\% bovine serum albumin (Fluka, St. Louis, M0, USA) and $0.05 \%$ Tween 20 . The following mouse monoclonal antibodies were used: antiHsp70 (Abcam), anti-mtHsp70 (Enzo Life Sciences) and anti-BrdU (BD; cross-reacting with $\mathrm{BrU}^{13}$, thus allowing to identify the $\mathrm{BrU}$ molecules incorporated in the newly transcribed RNAs). After rinsing, sections were floated on normal goat serum, and then reacted for $30 \mathrm{~min}$ at room temperature with the specific secondary $12 \mathrm{~nm}$ gold-conjugated antibody (Jackson Immuno Research Laboratories, West Grove, PA, USA) diluted 1:10 in PBS. The sections were finally rinsed, air-dried and
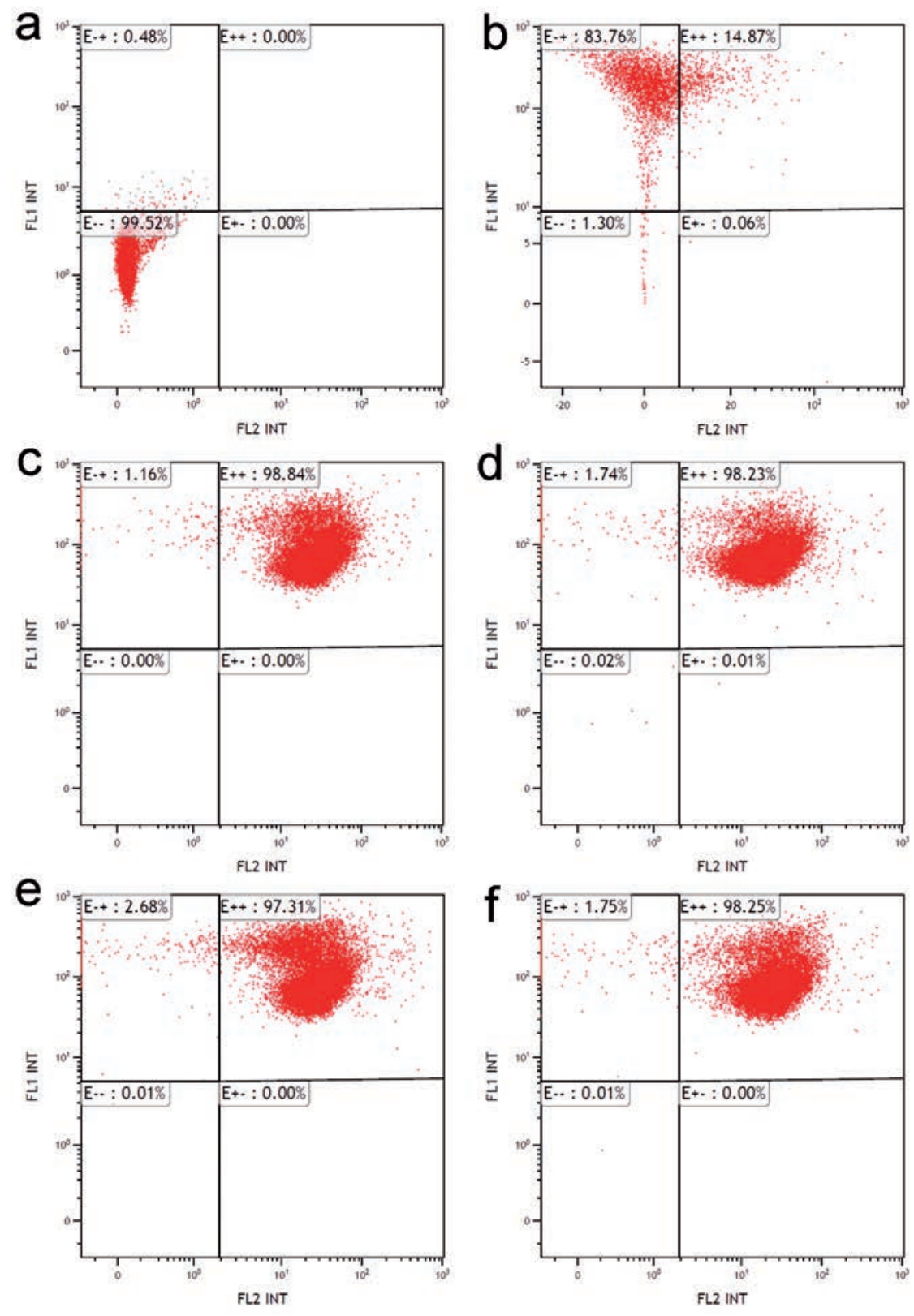

Figure 4. Effect of $\mathrm{O}_{3}$ exposure on mitochondrial membrane potential: flow cytometry of mitochondrial staining with JC-1. Autofluorescence control (a), negative red positive green fluorescence control (b), double positive red/green fluorescence control (air-treated cells) (c), cells exposed to $\mathrm{O}_{2}$ (d), cells exposed to $1 \mu \mathrm{g} \mathrm{O} / \mathrm{mL}$ (e), and $10 \mu \mathrm{g} \mathrm{O} / \mathrm{mL}$ (f). Note the similar fluorescence distribution in c,d,e and $\mathrm{f}$. 
selected areas were counted and the labelling density was expressed as number of gold grains $/ \mu \mathrm{m}^{2}$.

All samples were observed in a Philips Morgagni transmission electron microscope (FEI Company Italia Srl, Milan, Italy) operating at $80 \mathrm{kV}$ and equipped with a Megaview II camera (FEI Company Italia Srl) for digital image acquisition.

\section{Statistics}

Results for each measured variable were pooled according to the experimental group and the mean \pm standard error of the mean (SE) value calculated. Statistical comparisons were performed by the one way-Anova test and post-hoc pairwaise comparisons.

\section{Results}

\section{Cell viability and proliferation}

The Trypan blue test demonstrated that dead cells were lower than $1.5 \%$ in all samples at the different post-treatment times considered (Figure 1a); although higher values were found for cells treated with $20 \mu \mathrm{g} \mathrm{O}_{3} / \mathrm{mL}$, no significant difference was demonstrated. Accordingly, a similar pattern was found for the apoptotic cell percentage based on chromatin morphology after Hoechst 33342 staining (Figure 1b). The number of cells was similar in the samples from all the different treatments, after both $24 \mathrm{~h}$ and $48 \mathrm{~h}$ (Figure $2 \mathrm{a}$ ). Accordingly, BrdU incorporation did not show significant difference among samples $24 \mathrm{~h}$ and $48 \mathrm{~h}$ after treatment (Figure $2 \mathrm{~b}, \mathrm{c}$ ).

\section{Cell adhesion and flattening}

CTR cells and $\mathrm{O}_{2}$-treated samples showed similar values of adherent cells at all the posttreatment times considered. HeLa cells treated with $10 \mu \mathrm{g} \mathrm{O}_{3} / \mathrm{mL}$ showed significantly higher values, whereas significantly lower values were observed for cells treated with $20 \mu \mathrm{g} \mathrm{O}_{3} / \mathrm{mL}$ compared to the CTR and $\mathrm{O}_{2}$-treated samples. HeLa cells treated with $1 \mu \mathrm{gg} \mathrm{O}_{3} / \mathrm{mL}$ showed significantly higher values than CTR and $\mathrm{O}_{2}$-treated samples after $30 \mathrm{~min}$ and $1 \mathrm{~h}$, but for longer times the values became similar each other (Figure 3a). The percentage of flat cells was generally similar in CTR, $\mathrm{O}_{2}$-treated, $1 \mu \mathrm{gg}$ $\mathrm{O}_{3} / \mathrm{mL}$-treated and $20 \mu \mathrm{g} \mathrm{O}_{3} / \mathrm{mL}$-treated samples at $30 \mathrm{~min}, 1 \mathrm{~h}$ and $2 \mathrm{~h}$ after treatment; after $4 \mathrm{~h}$ and $6 \mathrm{~h}, \mathrm{O}_{2}$-treated cells showed lower values. Cells treated with $10 \mu \mathrm{g} \mathrm{O}_{3} / \mathrm{mL}$ showed significantly higher values at all post-treatment times (Figure 3b). Fluorescent phalloidin labelling of actin confirmed that, $24 \mathrm{~h}$ from treatment, cytoskeletal microfilaments of cells treated with $10 \mu \mathrm{g} \mathrm{O}_{3} / \mathrm{mL}$ were more distended than those of all the other conditions (Figure $3 \mathrm{c}$ ).

\section{In situ detection of Reactive Oxygen Species}

The cytochemical method based on a DAB$\mathrm{Mn}^{2+} \mathrm{CO}^{2+}$ reaction demonstrated that positive cells were less than $0.1 \%$ in all samples after both $30 \mathrm{~min}$ and $5 \mathrm{~h}$ post-treatment (not shown). Positive control cells treated with $9.8 \mathrm{M} \mathrm{H}_{2} \mathrm{O}_{2}$ showed diffuse and granular blue staining both in the cytoplasm and nucleus (not shown). On the basis of the results obtained for cell viability and kinetic cell features, only the ozone treatments inducing positive performance ( 1 and $10 \mu \mathrm{g} 0_{3} / \mathrm{mL}$ ) were further investigated for their effects on mitochondrial and nuclear function by means of cytometry, fluorescence microscopy and transmission electron microscopy.

\section{Mitochondrial membrane potential}

Flow cytometric analysis of mitochondrial
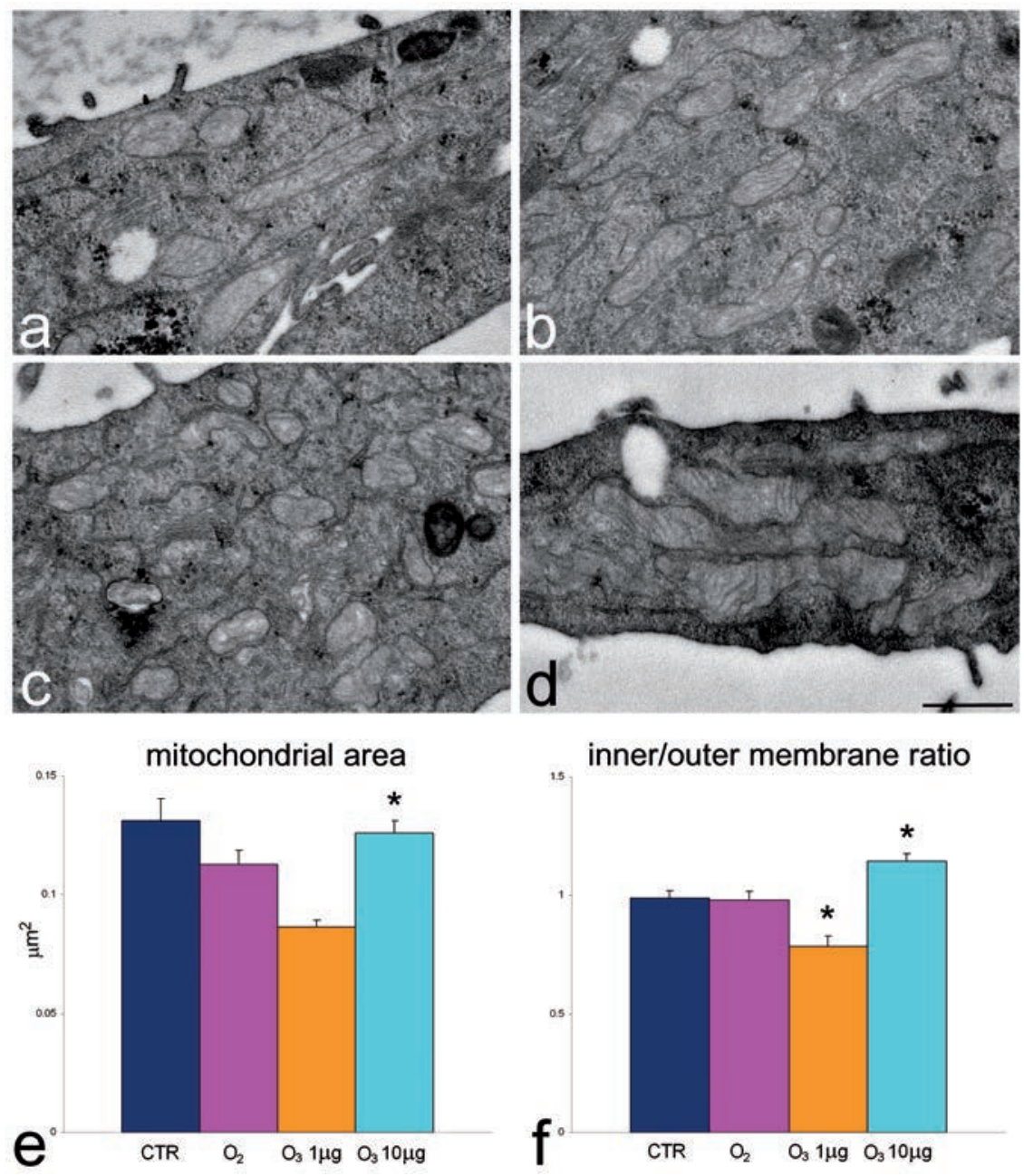

inner/outer membrane ratio

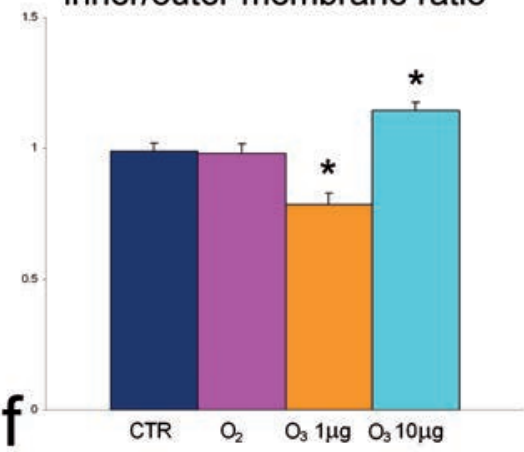

Figure 5. Effect of $\mathrm{O}_{3}$ exposure on mitochondrial ultrastructure: transmission electron micrographs of CTR (a), $\mathrm{O}_{2}$ (b), $1 \mu \mathrm{g} \mathrm{O}_{3} / \mathrm{mL}$-(c) and $10 \mu \mathrm{g} \mathrm{O} / \mathrm{mL}$ - (d) treated. In $1 \mu \mathrm{g}$ $\mathrm{O}_{3} / \mathrm{mL}$-treated cells mitochondria are small and contain scarce cristae whereas in $10 \mu \mathrm{g}$ $\mathrm{O}_{3} / \mathrm{mL}$-treated cells mitochondria are large with well developed cristae; scale bar: 500 nm. e,f) Mean $\pm S E$ values of mitochondrial area and inner/outer membrane ratio; asterisks indicate values significantly different from each other. samples showed similar values of red and green fluorescence, thus revealing similar

\section{Immunofluorescence microscopy}

Immunolabelling for Hsp70 showed a punctuate distribution of the protein in the cell nucleoplasm and a diffuse labelling in the cytoplasm, whereas the nucleolus was always ing of signal. No evident differences were ples. Labelling with the antiserum recognizing the mitochondrial $70 \mathrm{kDa}$ E2 subunit of the pyruvate dehydrogenase complex allowed visualization of all cell mitochondria; labelling for mtHsp70 mostly matched that for pyruvate dehydrogenase complex and did not demonstrate evident differences among the samples (not shown).
JC-1 incorporation demonstrated that all cell mounts of polarised and depolarised mito- 


\section{Ultrastructural morphology and immunocytochemistry}

Ultrastructural observations revealed similar morphological features in control, $\mathrm{O}_{2}$-treated, $1 \mu \mathrm{g} \mathrm{O}_{3} / \mathrm{mL}$-treated and $10 \mu \mathrm{g} \mathrm{O}_{3} / \mathrm{mL}$-treated HeLa cells after $24 \mathrm{~h}$ post-treatment. The only evident morphological difference concerned mitochondria of $\mathrm{O}_{3}$-treated cells: in fact, in $1 \mu \mathrm{g} \mathrm{O}_{3} / \mathrm{mL}$-treated cells the mitochondria appeared small and poor in cristae, whereas in $10 \mu \mathrm{g} \mathrm{O}_{3} / \mathrm{mL}$-treated cells the mitochondria showed well developed abundant cristae (Figure 5 a-d). Morphometric evaluations confirmed these observations (Figure 5 e,f). Immunocytochemical analyses demonstrated $\mathrm{BrU}$ incorporation in perichromatin fibrils and the nucleolar dense fibrillar component of all cell samples (Figure 6 a,b); quantitative evaluation revealed a significantly higher labelling density in both nucleoplasm and nucleolus of $10 \mu \mathrm{g} \mathrm{O}_{3} / \mathrm{mL}$-treated cells in comparison to the other samples (Figure $6 \mathrm{c}, \mathrm{d}$ ). Labelling for Hsp70 protein was found in the cytoplasm as a scattered signal while in the cell nucleus the labelling was specifically located in the perichromatin fibrils of all cell samples; in addition, in $10 \mu \mathrm{g} \mathrm{O}_{3} / \mathrm{ml}$-treated cells some nucleolar labelling was also observed (Figure 7 a,b). Quantitative evaluation demonstrated significant differences in labelling density among samples; in particular, $10 \mu \mathrm{g} \mathrm{O}_{3} / \mathrm{mL}$ treated cells showed lower cytoplasmic values and higher nucleoplasmic and nucleolar values in comparison to controls (Figure $7 \mathrm{c}$-e). Labelling for mtHsp70 protein was found inside mitochondria and as a weak scattered signal through the cytoplasm of all cell samples (Figure $8 \mathrm{a}, \mathrm{b}$ ); quantitative evaluation demonstrated significantly higher density of gold particles in the mitochondria of $10 \mu \mathrm{g} \mathrm{O}_{3} / \mathrm{mL}$-treated cells in comparison to the other samples (Figure 8c), whereas the cytoplasmic labelling did not significantly change among samples $\left(1.27 \pm 0.04\right.$ in CTR, $1.85 \pm 0.07$ in $0_{2}$-treated cells, $1.44 \pm 0.03$ in $1 \mu \mathrm{g} \mathrm{O}_{3} / \mathrm{mL}$-treated cells, and $1.76 \pm 0.06$ in $10 \mu \mathrm{g} 0_{3} /$ mL-treated cells).

Samples processed in the absence of primary antibodies revealed a negligible signal for all the probes used (not shown).

\section{Discussion}

In this study, the cytochemical and immunocytochemical approach used for investigating in situ the cellular response to low ozone concentrations provided original information on multiple effects on cytoplasmic and nuclear pathways which could account for the regenerative therapeutic potential. It is also worth underlying that, using an in vitro model, it was
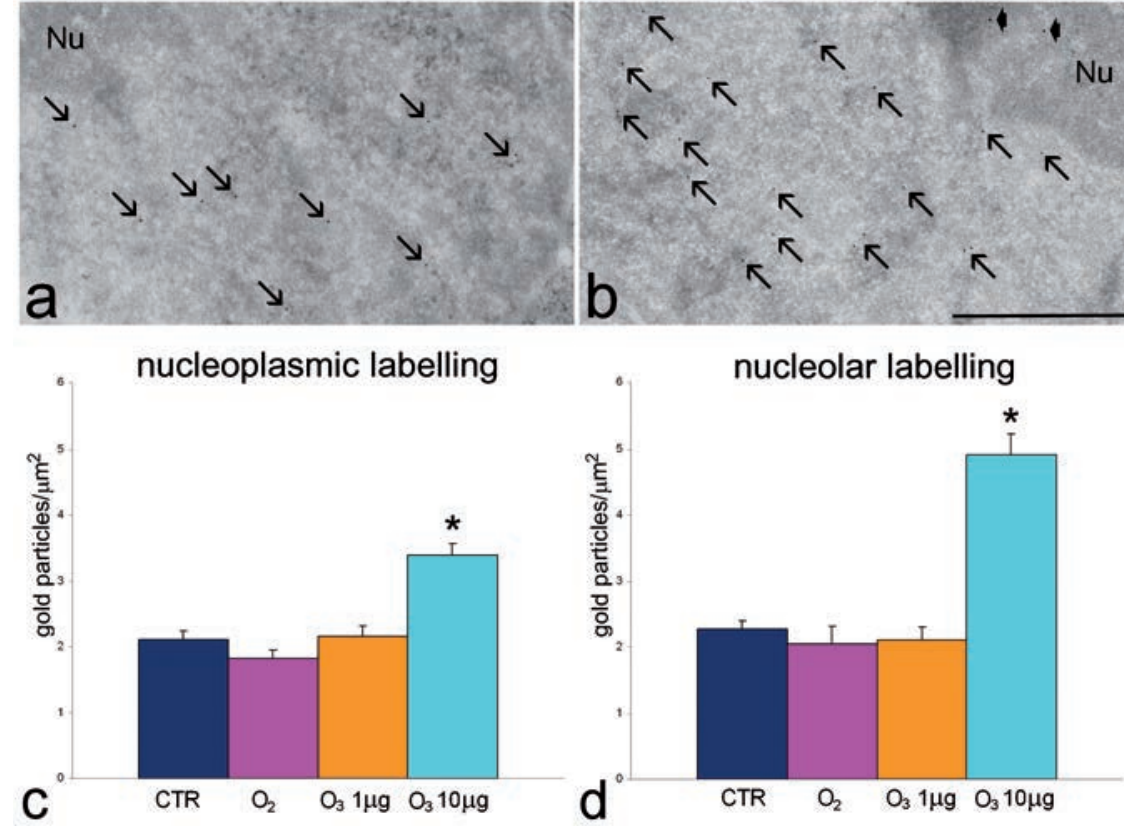

Figure 6. Effect of $\mathrm{O}_{3}$ exposure on RNA transcription: representative transmission electron micrographs of CTR (a) and $10 \mu \mathrm{g} \mathrm{O} / \mathrm{mL}$-treated cells (b) labelled for $\mathrm{BrU}$; $\mathrm{BrU}$ molecules have been incorporated in perichromatin fibrils (arrows) and in the nucleolar dense fibrillar component (arrowheads); Nu, nucleolus; scale bar: $500 \mathrm{~nm}$. c,d) Mean \pm SE values of $\mathrm{BrU}$ labelling density evaluated on nucleoplasm and nucleoli of cells incubated with $\mathrm{BrU} 24 \mathrm{~h}$ post-treatment; asterisks indicate values significantly different from each other.
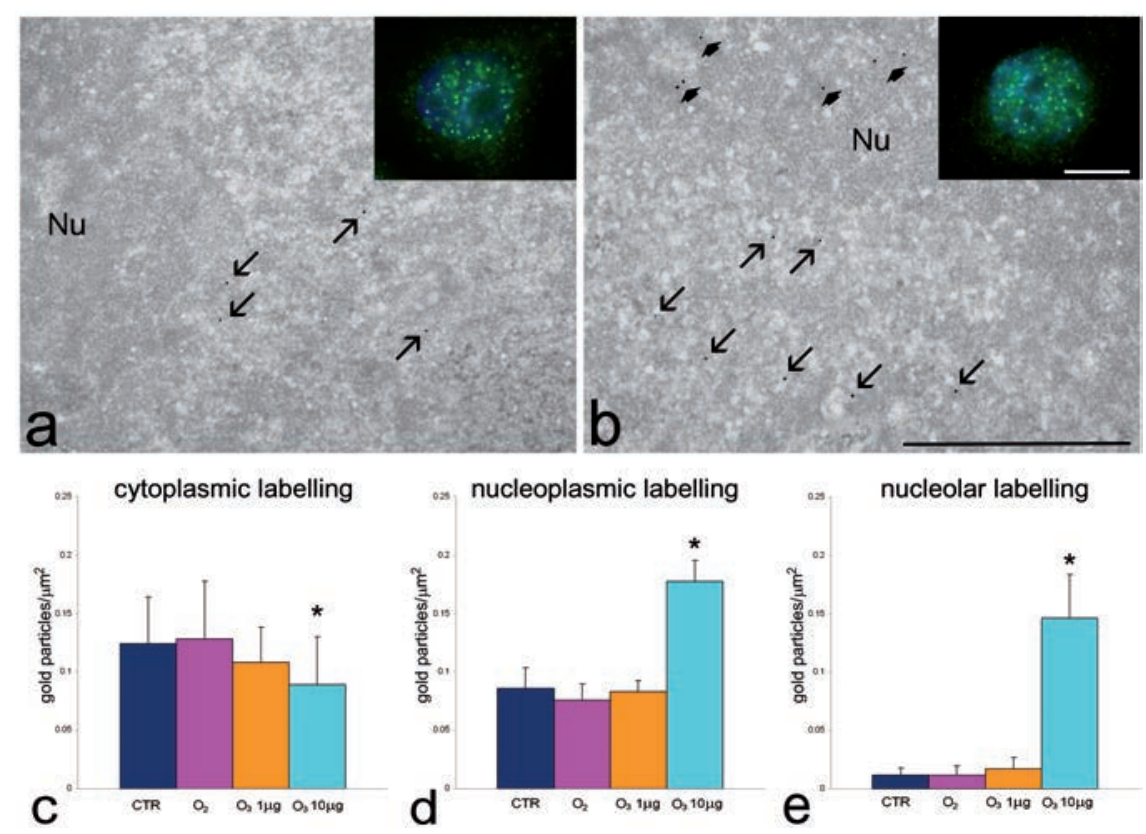

Figure 7. Effect of $\mathrm{O}_{3}$ exposure on $\mathrm{Hsp} 70$ cell distribution: representative fluorescence (insets) and transmission electron micrographs of CTR (a) and $10 \mu \mathrm{g} \mathrm{O} / \mathrm{mL}$-treated (b) cells labelled for Hsp70; the signal occurs in both cytoplasm and nuclei; perichromatin fibrils (arrows) and nucleoli (Nu, arrowheads) show specific labelling; scale bar: $500 \mathrm{~nm}$; inset scale bar: $10 \mu \mathrm{m}$. c-e) Mean \pm SE values of anti-Hsp70 labelling density evaluated on cytoplasm, nucleoplasm and nucleoli of cells $24 \mathrm{~h}$ post-treatment; asterisks indicate values significantly different from each other. 
possible to investigate the direct effects of mild ozonization on some cellular mechanisms, excluding the confusing influence of the organismic reaction occurring in animal models in vivo. Moreover, the reliability of the whole experimental procedure was guaranteed by choosing a well-established technique for cell ozonization. ${ }^{9}$ Interestingly, under our experimental conditions, oxygen exposure did not induce any significant effect in comparison to treatment with air, demonstrating that the cellular responses observed after treatment with the $\mathrm{O}_{2}-\mathrm{O}_{3}$ gas mixtures was actually due to ozone.

Our results demonstrated that exposure of HeLa cells to ozone concentrations ranging from 1 to $20 \mu \mathrm{g} / \mathrm{mL}$ did not induce significant alterations of their proliferation or death rate when compared to samples exposed to either $\mathrm{O}_{2}$ or air. On the other hand, ozone exposure proved to remarkably affect the capability of HeLa cells to restore, after the treatment in suspension, their typical morphology as flat cells adhering to the substrate, and this effect was manifestly related to the gas concentration. In fact, when compared to air or $\mathrm{O}_{2}$-treated samples, $20 \mu \mathrm{g} \mathrm{O}_{3} / \mathrm{mL}$-treated cells showed a significantly reduced adhering and flattening ability, whereas exposure to $10 \mu \mathrm{g} \mathrm{O}_{3} / \mathrm{mL}$ significantly improved adhesion/flattening; $1 \mu \mathrm{g}$ $\mathrm{O}_{3} / \mathrm{mL}$ had positive effects after short time but subsequently cell performance reverted to the control level.

It has been reported that ROS may affect in a dose-dependent manner the dynamics of cytoskeletal proteins (actin and myosin), high levels inducing protein depolymerization while low levels promoting polymerization and remodelling. ${ }^{14-16}$ In our experiments, ROS production was found to be minimal (as detected by the enzyme-histochemical approach used) with no consequence on cell viability; however, the effect on the polymerization of cytoskeletal proteins may likely depend on small local changes in ROS amounts. It can be thus hypothesised that, in our experimental model, exposure to $10 \mu \mathrm{g} \mathrm{O}_{3} / \mathrm{mL}$ led to an efficient reorganization of cytoskeletal elements, thus rapidly allowing cells to adhere and flatten, whereas $1 \mu \mathrm{g} \mathrm{O}_{3} / \mathrm{mL}$ treatment was only able to activate short-term positive effects; conversely, $20 \mu \mathrm{g} \mathrm{O}_{3} / \mathrm{mL}$ led to hindering of cytoskeletal reorganization after cell seeding. It has been reported ${ }^{17,18}$ that ozone exposure may increase in a dose-dependent manner the negative charges of the cell membrane, and this could also influence cell adhesion. It is, therefore, tempting to speculate that the effects of low ozone concentrations on the properties of the cell membrane and cytoskeleton may account for the observed positive effects of ozone therapy on wound healing. ${ }^{19-21}$

We found that the structure and functional features of mitochondria were significantly affected by mild ozonization (10 and $1 \mu \mathrm{g}$ $\mathrm{O}_{3} / \mathrm{mL}$ ) in comparison to the air- or $\mathrm{O}_{2}$-treated samples. Mitochondria are known to be very sensitive to even mild oxidative stress (recent review in ${ }^{22}$ ) and thus they represent an expected target for ozone. In particular, oxidative stress can induce mitochondrial fission, and ozone is known to cause alterations of the mitochondrial respiratory chain enzymes. ${ }^{23,24}$ However, low ROS concentrations can activate protective responses such as the expression of mtHsp70, ${ }^{25}$ a member of the HSP70 protein family whose expression is affected by ozone exposure ${ }^{26}$ and which is involved in multiple mitochondrial and extra-mitochondrial functions (reviews $\mathrm{in}^{27,28}$ ). We actually observed that $10 \mu \mathrm{g} \mathrm{O} / \mathrm{mL}$-treatment increased mitochondrial cristae length and mtHsp70 protein content, while $1 \mu \mathrm{g} \mathrm{O}_{3} / \mathrm{mL}$-treatment led to a decrease in mitochondrial size and cristae length, and did not affect mtHsp70. On the other hand, no significant modification of mitochondrial membrane potential was found under our experimental conditions.

Hsp70, another protein implicated in the response to stress (including heat shock and oxidative stress), was found to undergo intracellular redistribution in HeLa cells after $10 \mu \mathrm{g}$ $\mathrm{O}_{3}$ /ml-treatment. Hsp70 was already reported to be involved in ozone-induced response in vivo and in vitro, ${ }^{29-31}$ and in our model system we found that Hsp70 accumulated in the nucleoplasm (though maintaining the usual distribution in the perichromatin fibrils, i.e., the pre-mRNA transcription site ${ }^{32}$ ), and was also found in the nucleolus, which is usually devoid of this protein. This is consistent with reports in the literature on the accumulation of Hsp70 in nuclear and nucleolar transcriptional sites, as a response to various stresses, ${ }^{33-36}$ and with our observation that exposure to $10 \mu \mathrm{g} 0_{3} / \mathrm{mL}$ increased RNA transcription, as demonstrated by BrU incorporation in both nucleoplasm and nucleolus. Accordingly, ozone treatment has been demonstrated to activate expression of specific genes (review in ${ }^{8}$ ). It is worth noting that, at the concentrations used in this study, ozone exposure proved to preserve the normal ultrastructural features of cell organelles; in fact, no sign of degeneration was ever observed, and the morphological modifications occurring in mitochondria should be considered as the consequence of functional changes and not of organelle damage.

Taken together, our results demonstrate that, in our experimental model, $10 \mu \mathrm{g} \mathrm{O}_{3} / \mathrm{mL}$ treatment induces positive and long-lasting cellular responses in cytoskeletal organization and mitochondrial activation, as well as in nuclear transcription. On the other hand, $1 \mu \mathrm{g}$ $\mathrm{O}_{3}$ /mL-treatment seems to represent a stimulus able to activate some transient responses only. Ozone is an instable gas that rapidly decomposes to normal dioxygen; this implies that ozone can induce long-lasting positive biological effects through a cascade of finelytuned molecular events acting onto different cellular components and metabolic pathways. Our results confirm that the effects of ozone administration are dependent on gas concentration, and demonstrate that the nucleus and the cytoplasmic organelles may be differently affected. We are well aware that these data have been obtained in an in vitro cell model and cannot be directly translated to the application in vivo for therapy; nonetheless, the
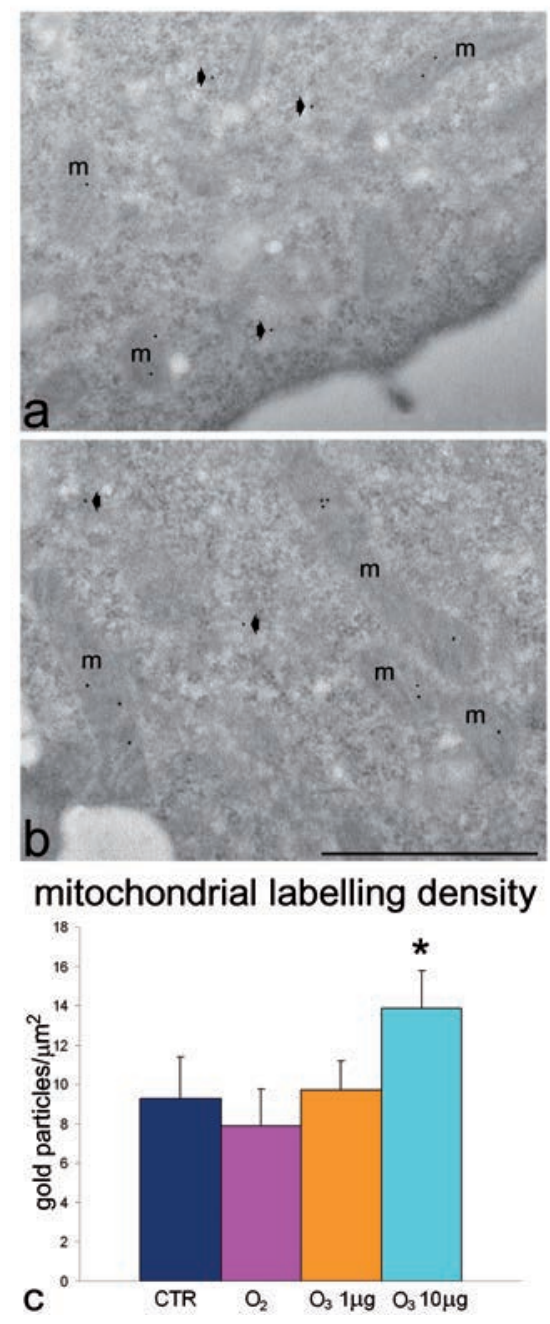

Figure 8. Effect of $\mathrm{O}_{3}$ exposure on mtHsp70 cell distribution: representative transmission electron micrographs of CTR (a) and $10 \mu \mathrm{g} \mathrm{O}_{3} / \mathrm{mL}$-treated (b) cells labelled for mtHsp70. The mitochondria (m) show specific labelling; some diffuse signal is present in the cytoplasm (arrowheads); scale bar: $500 \mathrm{~nm}$. c) Mean \pm SE values of anti-mtHsp70 labelling density evaluated on mitochondria $24 \mathrm{~h}$ posttreatment; asterisk indicates value significantly different from each other. 
evidence from the present experiments suggests that protocols of ozone administration may be developed to predictively ensure effective and permanent metabolic cell activation.

\section{References}

1. Re L, Mawsouf MN, Menéndez S, León OS, Sánchez GM, Hernández F. Ozone therapy: clinical and basic evidence of its therapeutic potential. Arch Med Res 2008;39:17-26.

2. Elvis AM, Ekta JS. Ozone therapy: A clinical review. J Nat Sc Biol Med 2011;2:66-70.

3. Bocci V. How a calculated oxidative stress can yield multiple therapeutic effects. Free Radic Res 2012;46:1068-75.

4. Bocci V, Zanardi I, Travagli V. Potentiality of oxygen-ozone therapy to improve the health of aging people. Curr Aging Sci 2010; 3:177-87.

5. El-Sawalhi MM, Darwish HA, Mausouf MN, Shaheen AA. Modulation of age-related changes in oxidative stress markers and energy status in the rat heart and hippocampus: a significant role for ozone therapy. Cell Biochem Funct 2013;31:518-25.

6. Shehata NI, Abd-Elgawad HM, Mawsouf MN, Shaheen AA. The potential role of ozone in ameliorating the age-related biochemical changes in male rat cerebral cortex. Biogerontology 2012;13:565-81.

7. SCO3 - International Scientific Committee of Ozonetherapy. (Madrid, 2012). Ozone therapy and its scientific foundations. Available from: http//www.isco3.org

8. Sagai M, Bocci V. Mechanisms of action involved in ozone therapy: is healing induced via a mild oxidative stress? Med Gas Res 2011;1:29.

9. Larini A, Bianchi L, Bocci V. The ozone tolerance: I) Enhancement of antioxidant enzymes is ozone dose-dependent in Jurkat cells. Free Radical Res 2003;37: 1163-8.

10. Freitas I, Griffini P, Bertone V, Bertone R, Fenoglio C, Milliery R, et al. In situ detection of reactive oxygen species and nitric oxide production in normal and pathological tissues: improvement by differential interference contrast. Exp Gerontol 2002;37:591-602.

11. Reers M, Smith TW, Chen LB. J-aggergate formation of a carbocyanine as a quantitative fluorescent indicator of membrane potential. Biochemistry 1991;30:4480-6.

12. Bottone MG, Soldani C, Veneroni P, Avella D, Pisu M, Bernocchi G. Cell proliferation, apoptosis and mitochondrial damage in rat B50 neuronal cells after cisplatin treatment. Cell
Prolif 2008;41:506-20.

13. Jensen P0, Larsen J, Christiansen J, Larsen JK. Flow cytometric measurement of RNA synthesis using bromouridine labelling and bromodeoxyuridine antibodies. Cytometry 1993;14:455-8.

14. Sakai J, Li J, Subramanian KK, Mondal S, Bajrami B, Hattori H, et al. Reactive oxygen species (ROS)-induced actin glutathionylation controls actin dynamics in neutrophils. Immunity 2012;37:1037-49.

15. Taulet N, Delorme-Walker VD, DerMardirossian C. Reactive oxygen species regulate protrusion efficiency by controlling actin dynamics. PLoS ONE 2012;7:e41342.

16. Muliyil S, Narasimha M. Mitochondrial ROS regulates cytoskeletal and mitochondrial remodeling to tune cell and tissue dynamics in a model for wound healing. Dev Cell 2014;28:239-52.

17. Travagli V, Zanardi I, Silvietti A, Bocci V. A physicochemical investigation on the effects of ozone on blood. Int $\mathrm{J}$ Biol Macromol 2007;41:504-11.

18. Artis AS, Aydogan S, Sahin MG. The effects of colorectally insufflated oxygen-ozone on red blood cell rheology in rabbits. Clin Hemorheol Microcirc 2010;45:329-36.

19. Jacinto A, Martinez-Arias A, Martin P. Mechanisms of epithelial fusion and repair. Nat Cell Biol 2001;3:E117-23.

20. Cowin AJ, Hatzirodos N, Teusner JT, Belford DA. Differential effect of wounding on actin and its associated proteins, paxillin and gelsolin, in fetal skin explants. J Invest Dermatol 2003;120:1118-29.

21. Lees JG, Ching YW, Adams DH, Bach CT, Samuel MS, Kee AJ, et al. Tropomyosin regulates cell migration during skin wound healing. J Invest Dermatol 2013;133:1330-9.

22. Mailloux RJ, Jin X, Willmore WG. Redox regulation of mitochondrial function with emphasis on cysteine oxidation reactions. Redox Biol 2014;2:123-39.

23. Madej P, Plewka A, Madej JA, Plewka D, Mroczka W, Wilk K, et al. Ozone therapy in induced endotoxemic shock. II. The effect of ozone therapy upon selected histochemical reactions in organs of rats in endotoxemic shock. Inflammation 2007;30:69-86.

24. Lintas G, Molinari F, Simonetti V, Franzini M, Liboni W. Time and time-frequency analysis of near-infrared signals for the assessment of ozone autohemotherapy long-term effects in multiple sclerosis. Conf Proc IEEE Eng Med Biol Soc 2013;2013:6171-4.

25. Liu Y, Liu W, Song X-D, Zuo J. Effect of GRP75/mthsp70/PBP74/mortalin overexpression on intracellular ATP level, mitochondrial membrane potential and ROS accumulation following glucose deprivation in PC12 cells. Mol Cell Biochem 2005;268:45-51.

26. Wu R, Zhao YH, Plopper CG, Chang MM, Chmiel K, Cross JJ, et al. Differential expression of stress proteins in nonhuman primate lung and conducting airway after ozone exposure. Am J Physiol 1999;277:L511-22.

27. Wadhwa R, Taira K, Kaul SC. An Hsp70 family chaperone, mortalin/mthsp70/PBP74/Grp75: what, when, and where? Cell Stress Chaperones 2002;7:309-16.

28. Flachbartová Z, Kovacech B. Mortalin - a multipotent chaperone regulating cellular processes ranging from viral infection to neurodegeneration. Acta Virol 2013;57:3-15.

29. Cardile V, Jiang X, Russo A, Casella F, Renis $\mathrm{M}$, Bindoni M. Effects of ozone on some biological activities of cells in vitro. Cell Biol Toxicol 1995;11:11-21.

30. Bocci V, Aldinucci C, Mosci F, Carraro F, Valacchi G. Ozonation of human blood induces a remarkable upregulation of heme oxygenase-1 and heat stress protein-70. Mediators Inflamm 2007;2007:26785.

31. Bauer AK, Rondini EA, Hummel KA, Degraff LM, Walker C, Jedlicka AE, et al. Identification of candidate genes downstream of TLR4 signaling after ozone exposure in mice: a role for Heat-Shock Protein 70. Environ Health Perspect 2011; 119:1091-7.

32. Fakan S. Ultrastructural cytochemical analyses of nuclear functional architecture. Eur J Histochem 2004;48:5-14.

33. Nollen EA, Salomons FA, Brunsting JF, van der Want JJ, Sibon OC, Kampinga HH. Dynamic changes in the localization of thermally unfolded nuclear proteins associated with chaperone-dependent protection. Proc Natl Acad Sci USA 2001;98:12038-43.

34. Kotoglou P, Kalaitzakis A, Vezyraki P, Tzavaras T, Michalis LK, Dantzer F, et al. Hsp70 translocates to the nuclei and nucleoli, binds to XRCC1 and PARP-1, and protects HeLa cells from single-strand DNA breaks. Cell Stress Chaperones 2009;14:391-406.

35. Ba ski P, Mahboubi H, Kodiha M, Shrivastava S, Kanagaratham C, Stochaj U. Nucleolar targeting of the chaperone hsc70 is regulated by stress, cell signaling, and a composite targeting signal which is controlled by autoinhibition. J Biol Chem 2010;285:21858-67.

36. Khalouei S, Chow AM, Brown IR. Localization of heat shock protein HSPA6 (HSP70B') to sites of transcription in cultured differentiated human neuronal cells following thermal stress. J Neurochem 2014;131:743-54. 